\title{
False High Parathormone Levels Due to Preanalytical Differences in Patient With Parathyroid Gland Autotransplantation
}

\author{
Cevdet Duran ${ }^{\mathrm{a}, \mathrm{e}}$, Orkide Kutlu ${ }^{\mathrm{b}}$, Mustafa Caycic ${ }^{\mathrm{c}}$, Ferda Sevimli Burnik ${ }^{\mathrm{a}}$, Omer Karahan ${ }^{\mathrm{d}}$, \\ Uysaler Aslan ${ }^{\mathrm{b}}$, Samil Ecirli ${ }^{\mathrm{b}}$
}

\begin{abstract}
High parathormone (iPTH) values in the patients having parathyroid autotransplantations can be derived from parathyromatosis or preanalytical differences. In this report, we presented a patient with kidney failure and factitiously high iPTH levels. Because of tertiary hyperparathyroidism, total parathyroidectomy and $1 / 2$ parathyroid tissue autotransplantation to brachioradial muscle in right forearm operation has been performed. Although he has been followed with high iPTH levels for a long time, he does not have parathyromatosis. iPTH level was found normal when blood samples were taken from the other arm. High iPTH levels are thought to be related to the place where the blood samples taken i.e., samples taken from the proximal region of autotransplantation, we recommend the blood sample should be taken from the contralateral or distal region of the autotransplantation in order to avoid misdiagnosis and unnecessary and incorrect procedures in patients with parathyroid autotransplantation.
\end{abstract}

Keywords: Renal failure; Parathyroid autotransplantation; High parathormone level; Preanalytical difference

\section{Introduction}

Tertiary hyperparathyroidism (THPT) is a serious and important complication in patients with advanced renal insufficiency [1]. Total parathyroidectomy with immediate par-

\footnotetext{
Manuscript accepted for publication August 20, 2013

a Division of Endocrinology, Department Internal Medicine, Konya Training and Research Hospital, Konya, Turkey

${ }^{\mathrm{b}}$ Division of Internal Medicine, Konya Training and Research Hospital, Konya, Turkey

${ }^{\mathrm{c}}$ Department of Nuclear Medicine, Konya Training and Research Hospital, Konya, Turkey

${ }^{\mathrm{d}}$ Department of General Surgery, Konya Training and Research Hospital, Konya, Turkey

${ }^{\text {e}}$ Corresponding author: Cevdet Duran, Division of Endocrinology, Department Internal Medicine, Konya Training and Research Hospital, Konya, Turkey. Email: drcduran@gmail.com

doi: http://dx.doi.org/10.4021/jmc1497w
}

tial parathyroid autotransplantation is an alternative method for treatment of THPT [2]. In this procedure; bilateral neck exploration and total parathyroidectomy are performed and $1 / 2$ parathyroid tissue is implanted to the parasternal region or brachioradial muscle of forearm [3]. Generally, the arm without fistulae is preferred in forearm autotransplantations.

The state of high impact parathormone levels (iPTH) continuing after surgery is called parathyromatosis [4-7]. Enlargement of the parathyroid tissue that is seeded or implanted on forearm is blamed for parathyromatosis. The frequency of parathyromatosis in forearm autotransplantations is reported between $0.11 \%$ and $58 \%[6,7]$. Another cause of high iPTH level after total parathyroidectomy with autotransplantation is due to preanalytical differences. Factitiously high iPTH levels can be found if blood samples were taken proximal vein to the site of parathyroid autotransplantation [8-11]. Here we presented a patient with total parathyroidectomy and $1 / 2$ parathyroid tissue autotransplantation to right brachioradial muscles in the forearm operation (contralateral to the arterious-venous fistulae) has been performed due to tertiary hyperparathyroidism. Although he did not have parathyromatosis, he has been followed with high iPTH value for a long time.

\section{Case Report}

A fifty-six years old male patient has had chronic kidney failure and hemodialysis treatment for 15 years. Ten years ago, total parathyroidectomy and $1 / 2$ parathyroid gland autotransplantation to the brachioradial muscle in the right forearm operation had been performed due to tertiary hyperparathyroidism. Living donor renal transplantation had been performed 4 years ago. Before the transplantation, iPTH levels were between 90 and $477 \mathrm{pg} / \mathrm{ml}(\mathrm{N}$ : $11-67 \mathrm{pg} /$ $\mathrm{mL}$ ), after renal transplantation iPTH levels were between 190 and $1853 \mathrm{pg} / \mathrm{ml}$. Parathyroidomatosis had been suspected and scintigraphic imaging with Tc-99m MIBI had been done and no focus had been found in another center. When he admitted to our out-patient clinic, his laboratory analysis showed that; iPTH value was $2382 \mathrm{pg} / \mathrm{mL}$, calcium $9.2 \mathrm{mg} /$ $\mathrm{dL}(\mathrm{N}: 8.4-10.2 \mathrm{mg} / \mathrm{dL})$, phosphorus $4.2 \mathrm{mg} / \mathrm{dL}(\mathrm{N}: 2.5-4.5$ 
$\mathrm{mg} / \mathrm{dL}$ ), albumin $3.9 \mathrm{~g} / \mathrm{dL}(\mathrm{N}: 3.5-5 \mathrm{~g} / \mathrm{dL}$ ), urea $45 \mathrm{mg} / \mathrm{dL}$ $(\mathrm{N}: 15-55 \mathrm{mg} / \mathrm{dL}$ ), creatinine $1.51 \mathrm{mg} / \mathrm{dL}(\mathrm{N}: 0.7-1.3 \mathrm{mg} /$ $\mathrm{dL}$ ). Vitamin $\mathrm{D}$ was not measured. In order to understand whether the raised level of iPTH values are due to the area where the blood samples were taken from, samples were taken both from the right arm (proximal and distal from the region where the implantation was done) and from the left (contralateral) arm. iPTH values were detected as $1,863 \mathrm{pg} /$ $\mathrm{mL}$ in the sample taken from the right forearm proximal site of autotransplantation, and $75.6 \mathrm{pg} / \mathrm{mL}$ in the sample from the distal and $30 \mathrm{pg} / \mathrm{mL}$ from the left arm sample. It became apparent that the differences between the iPTH values are due to the place of the blood samples taken.

\section{Discussion}

In patients with parathyroid gland autotransplantations, preanalytic factors such as the place of blood samples taken may cause high iPTH levels except parathyromatosis. In patients with renal failure, it is avoided to take blood samples from arm with arterious-venous fistulae. This causes factitious and incorrect iPTH levels for patients with parathyroid autotransplantations and in the literature, there are limited knowledge for this problem [8-11]. The fact that autotransplants veins drain to antecubital veins, the parathormone released from autotransplant to antecubital veins also. That causes extremely high and incorrect iPTH values if blood samples are taken from the proximal region of arm having autotransplantation [8-11].

Conclusively, we recommend in order to avoid misdiagnosis and leading to unnecessary and incorrect procedures, the blood sample should be taken from the contralateral or distal site of the autotransplantation. In the evaluation of parathyroid functions, not only the iPTH level, but also the other biochemical parameters should be assessed together at the same time.

\section{Conflict of Interest}

There is no conflict of interest.

\section{References}

1. Salem MM. Hyperparathyroidism in the hemodialysis population: a survey of 612 patients. Am J Kidney Dis. 1997;29(6):862-865.

2. Kievit AJ, Tinnemans JGM, Idu MM, Groothoff JW, Surachno S, Aronson DC. Outcome of total parathyroidectomy versus and autotransplantation as treatment of secondary and tertiary hyperparathyroidism in children and adults. World J Surgery. 2010;34:993-1000.

3. Baumann DS, Wells SA, Jr. Parathyroid autotransplantation. Surgery. 1993;113(2):130-133.

4. Wu TJ, Wang YT, Chang H, Lin SH. Parathyromatosis. Kidney Int. 2012;82(10):1140.

5. Hage MP, Salti I, El-Hajj Fuleihan G. Parathyromatosis: a rare yet problematic etiology of recurrent and persistent hyperparathyroidism. Metabolism. 2012;61(6):762775 .

6. Matsuoka S, Tominaga Y, Sato T, Uno N, Goto N, Katayama A, Uchida K, et al. Recurrent renal hyperparathyroidism caused by parathyromatosis. World J Surg. 2007;31(2):299-305.

7. Melck AL, Carty SE, Seethala RR, Armstrong MJ, Stang MT, Ogilvie JB, Yip L. Recurrent hyperparathyroidism and forearm parathyromatosis after total parathyroidectomy. Surgery. 2010;148(4):867-873; discussion 873865.

8. Hickey RC, Samaan NA. Human parathyroid autotransplantation: proved function by radioimmunoassay of plasma parathyroid hormone. Arch Surg. 1975;110(8):892-895.

9. Martins de Castro MC, Jorgetti V. Assessment of parathyroid hormone secretion before and after total parathyroidectomy with autotransplantation. Nephrol Dial Transplant. 1999;14(9):2264-2265.

10. Remijn JA, Beukhof JR, Dikkeschei LD. Large fluctuations in parathyroid hormone concentrations after autotransplantation of parathyroid tissue in the forearm. Clin Chem. 2007;53(3):534-535.

11. Bell DS. Apparent Recurrence of Hyperparathyroidism following Quadruple Parathyroidectomy. Case Rep Endocrinol. 2013;2013:912701. 